\title{
Identifying Silence Climate in Organizations in the Framework of Contemporary Management Approaches
}

\section{Mustafa Emre CIVELEK}

Lecturer, Istanbul Commerce University, Istanbul, Turkey

\section{Mehmet Saim AŞÇI}

Lecturer, Istanbul Medipol University, Istanbul, Turkey

\section{Murat ÇEMBERCI}

Lecturer, Istanbul Commerce University, Istanbul Turkey

\begin{abstract}
Dynamic competition conditions in present day bring about the consequence for businesses to face varied problems with each passing day. At this point, current management approaches include studies that would shed light on the new problems of businesses. Organizational Silence, a concept that has recently been being voiced in business world, has come up in such context. Organizational silence could be expressed as the employee behavior of keeping silent about certain negativities due to various reasons in an organization. Since knowledge sharing in modern organizations is of capital importance in terms of responding hastily to the changes in a competitive environment, spread of this behavior of employees to organization culture and climate presents a threat of indifference. In this study, the concept of Organizational Silence is defined and the effects of conceived silence climate on management of organizations are discussed.
\end{abstract}

Key Words: Organizational Silence, Organizational Culture, Silence Climate

JEL classification: $M 12$, M14

\section{Introduction}

In modern-day's extremely competitive environment, it is of vital important for organizations to possess an organizational structure and culture that adapt rapidly to the changes in the environment conditions. The primary factor that will ensure organizations to act fast to these changes is the healthy realization of intra-organizational communication and knowledge sharing. Yet in some organizations, such information sharing and communication are obstructed in various ways. Among them is the problem referred as organizational silence. 


\section{Civelek et al. /International Journal of Research in Business and Social Science Vol 4, No 4, 2015 ISSN: 2147-4478}

Organizational silence could be expressed as the employee behavior of keeping silent about certain negativities due to various reasons in an organization. Since knowledge sharing in modern organizations is of capital importance in terms of responding hastily to the changes in a competitive environment, spread of this behavior of employees to organization culture and climate presents a threat of indifference.

Employees collecting information, sharing it, creating new information using this information and using the information that they created to efficiently solve the problem, sharing with each other the processes that they find erroneous in the organization and trying to fix them are the primary factors that provide a competitive advantage to the organization (Çemberci, 2012). Creative employees that take responsibility and initiative are crucial in the rapidly changing and increasingly toughening up competition environment. Although the significance of employee empowerment is put forward in scientific studies about management, in practice, the phenomenon of organizational silence prevails in many corporations. Employees may suffer from the fear of being perceived as a troublemaker when they pass a remark, or they may believe that their proposals would not bring about change, nor be taken into consideration. Such behaviors that employees exhibit correlate with the concept of organizational silence (Alparslan \& Kayalar, 2012).

\section{Conceptual Framework}

\section{Organizational Silence}

Lexically, silence means the state of lack of noise in the environment, quite (Türk Dil Kurumu Büyük Türkçe Sözlük). Conceptually, silence can be seen as closely associated with notions such as modesty, respect and grace. Silence can also be defined as the act of avoiding confronting with problems. In an organization, people may stay silent due to confrontations, feeling of embarrassment, marginalization, indifference, anxiety, various perceived dangers, economical reasons or fear of losing their job. In some cases, silence may emerge as a strategic and proactive behavior to hide classified information about the organization. Besides that, organization members may keep silent to exhibit that they adopt a decision (Alparslan, 2010).

Although the concept of silence expresses the state of being silent, it can also be considered as a method of communication. By keeping silent, employees get the message of actually being dissatisfied or different messages as occasions require across managers (Özgen \& Sürgeyil, 2009).

Pioneer study in silence was conducted by Hirschman in 1970. Hirschman defined silence, unlike the usage we have today, as a constructive reaction that is passive but in the same lines as commitment (Eroğlu, Adıgüzel, \& Öztürk, 2011). In a 1973 study, Jensen sets forth the five binary functions of organizational silence. These functions are listed as follows (Taşkıran, 2011):

1. It both gathers individuals and drives them apart.

2. It may disrupt the relationship among individuals and hurt them as well as enhancing their relationships.

3. Sometimes it provides knowledge, sometimes it hides the knowledge.

4. It indicates deep thought as well as the lack of thought.

5. It may be considered as an indicator of both approval and refusal.

Peter Senge who did the classical study about learning organizations approach in 1990 and formed his opinions about the matter based on the systems approach, identifies the learning disabilities in organizations. One such disability that was put forward by Senge is the myth of the management team. Management teams are constituted by aggregating experienced managers who represent different expertise areas in organizations. However teams organized in such a way try to suppress disagreements among the member in order to preserve the image of a consistent team. According to Cris Argyris, many corporations cause the surfacing of this situation by rewarding those who avoid complicated problems and who do not persist in their opinions (Senge, 2004).

In a 2005 study by Huang et al., it is emphasized that although the organizational silence starts as an individual phenomenon, in time, it transforms into climate. That is to say, it emerges as a collective behavior, favored by the majority of the employees. Employees choose to stay silent especially when they think that sharing their opinions would cause adverse outcomes, or that it would harm their relationships with others (Huang, Vegt, \& Viert, 2005). 
According to the study done by Tangirala and Ramanujam in 2008, organizational silence is the case where the members of the organization would not disclose their opinions on the organization to the individuals with the power of interference in the situation (Tangiralay \& Ramanujam, 2008).

About the silence decision of employees, Expectancy Theory was put forward by Vroom in 1964, and Theory of Reasoned Action was proposed by Ajzen in 1975. As stated by the Expectancy Theory and the Theory of Reasoned Action, if it is thought that an action would have desired outcomes or it would prevent an undesired outcome, the individual would have a positive attitude towards realizing this action. From the viewpoint of silence, if individuals would believe that speaking up openly would not result in positive outcomes, they would interpret acting like that as less important, therefore they may gradually become silent. Likewise, Rosen and Tesser put forward the phenomenon of MUM Effect in 1970. MUM Effect is the out of place feeling of employees when they are about to give to the managers the information on the existing problems and the activities that are being misconducted. Another theory that opting to stay silent is based on is Spirals of Silence Theory developed by Noelle and Neumann in 1974. According to Spirals of Silence Theory, the community would ostracize the individuals unless they conform to majority's ideas. Individuals feel the need to avoid becoming isolated and to be accepted by the society. Fear of ostracism would ensure people to join the majority, even though they do not agree. As a result of social pressure, the individual may opt not to take a stand (Çakıc1, 2007).

Bowen and Blackmon takes a look at Noelle and Neumann's Spirals of Silence Theory from an organizational viewpoint and claims that personnel would keep quiet unless they receive support from colleagues. If employees think that there is resistance to speaking up, they would choose silence. Eventually, the choice between keeping silent and speaking up is mainly affected by the dominant opinion among the work group and the perceived organizational climate (Gül \& Nazlı Özcan, 2010).

Another theory is the Abilene Paradox that was put forward by Harvey in 1988. Abilene Paradox occurs when the individual keeps silent and does not argue against the overall opinion of the group despite it does not conform to his or her opinion (Alparslan, Örgütsel Sessizlik İklimi ve İş gören Sessizlik Davranışları Arasındaki Etkileşim, 2010).

"Deaf Ear Syndrome" Theory was put forward by Pierce et al. in 1998. Deaf Ear Syndrome shows up when employees feels turning a deaf ear to flaws and negativities as a positive reaction. According to Pierce et al., Deaf Ear Syndrome may consist of three factors (Alparslan, 2010):

1. Unqualified and inadequate organization policies.

2. Valuable personnel being constantly under protection, whereas others are being overlooked and being condemned even when they are the victim.

3. Being a family business, small business or a male-dominated business.

According to a study done by Morrison and Milliken in 2000, organizational silence may lead to feelings of unworthiness, sense of lack of control and cognitive dissonance (Özdemir \& Sarığlu Uğur, 2013).

\section{The Factors of Organizational Silence Climate}

There are various factors which create the silence climate in organizations. One such factor is the employers' fear of being criticized by the personnel. Especially the inadequate managers with low self - esteem possess likely concerns. Managers as such pretend not to have heard the employees' demands, or act like they do not care about them. In case of a negative feedback from the personnel, managers with low self - esteem usually place the blame on someone else, rather than self-criticism.

Another factor contributing to the silence climate in organizations is the belief of managers about the employees. Some managers have the opinion that employees are selfish and they are not to be trusted. The second belief of some managers is the belief that themselves know best what is for the benefit of the organization. And the third belief that the managers have is the belief that discrepancies, incompatibilities and conflicts should be avoided in an organization. Such managers see different thoughts as a source of conflict and they would try to suppress diversified opinions.

Another factor that constitutes the silence climate in organization is the organizational structure. Notably, hierarchic organizational structures, limit participation of employees in administration and the flow of information, therefore promote silence climate (Durak, 2012). 
A variety of reasons for keeping silent behavior of employees exist. Traits such as age, gender, education, experience stands out for individuals to opt for keeping silent behavior in organization. For instance, an employee may prefer silence behavior as the employee's level of accord rises as he or she is getting aged. As regards to gender, studies show that female employees opt more for keeping silent. Lastly, as educational level lowers, the tendency to exhibit silence behavior increases since the ability of self-expression and to express knowledge (Taşkıran, 2011).

\section{Organizational Silence Climate}

The formation of organizational silence may directly be linked to organization culture. Organizational silence is a climate and it arises as a consequence of organization culture. In broad sense, culture can be defined as an aggregate consisting of elicited and shared values, embraced beliefs, behavioral patterns, symbols and slogans of people. In this general culture, subcultures sharing different values, beliefs and symbols may develop. Clark Wissler defines Culture as: "Culture is the lifestyle of a community" (Turhan, 1987). Every business is actually a small community. Hence, this small community will have a set of shared values, namely, culture. In this context, organization culture can be considered as a subculture that is formed under the general culture that is embraced by the society of the country where the organization operates (Koçel, 2011).

According to Camerer and Peters, the culture of the community of which employees' are a member, affects their behavior in the organization. Moreover, in reference to Gordon and Smith's 1991 and 1992 studies, organizational behavior in organizations that operates in different countries varies with the community culture (Essounga, 2009). That is to say, the organization itself is a phenomenon of culture that changes in accordance with the development of the community (Morgan, 1998).

It is thought that organizational silence is related to the cultural features of the society which the affiliates of organization are a member of. In this context, the emphasis is mostly on power distance and learned helplessness concepts.

Power distance is one of the five social value dimensions affecting the organization and the work relations of employees which is suggested by Hofstede. Power distance can be explained as the degree of espousing the difference of power among people and institutions (Mooji \& Hofstede, 2010). For example, in countries where the power distance is excessive, it is unimaginable for employees to criticize the managers. In countries with a high power distance, the dominant idea is that manager knows the best (Doğan, 2007).

Learned helplessness is a concept that was suggested in a 1978 study by Abramson, Selingman and Tasdale. People having failed attempts in previous experiences, give way to feelings of helplessness and do not take steps in the future, even if they are able to control the outcome with their behavior. This situation is called learned helplessness (Bayat, 2002).

We have previously stated that organizational silence is a collective behavior rather than individual. Personal difficulties, judgements and feelings arise from the social values of people. These cause a psychological distance, much like physical distance. Psychological distance may completely obstruct a communication (Keith, 1988). In time individual silence conducts develop into a collective case, leading to silence climate in organization. Climate may be defined as the air, or the setting created by the prevalent organization culture. Climate is a sub-dimension of culture and is based upon perception. Though it is group perception. Organizational silence climate is a phenomenon observed in organizations where the fear culture is dominant. In organizations where fear culture prevails, the emotion of fear is used to obligate employees to behave in a certain way, or contrarily, keep them clear of certain behaviors. In such case, the individual submits to the authority without thinking, questioning or generating an idea since he or she feels weak in the face of authority. This case leads to the emergence of silence culture.. Some managers think that they achieve discipline through fear, however the discipline established by fear is not a long - term and genuine discipline. Because the discipline is gone when the fear disappears. In fact, the discipline needs to be internalized by employees without the existence of fear (Durak, 2012). In the 2000 study by Morrison and Milliken, the causes of organizational silence are stated as (Burçin, 2012):

- Lack of different knowledge input

- Lack of criticism raised against opinions and thoughts

- Lack of inherent feedback 
- Thought of employees being unworthy

- Employees' perception of lack of control

- Cognitive dissonance of employees

\section{The Types of Silence}

Most widely used classification is the ternary classification of Dyne, Ang and Botero. In the lines of this classification, organizational silence divides into three types, namely acquiescent silence, defensive silence and prosocial silence.

\section{Acquiescent Silence}

It occurs in the form of employees keeping silent in case of acceptance of the current state. The individuals embracing this behavior show tendency to accept the organizational conditions as are. The belief that adverse outcomes would appear when speaking up, causes the employees to comply with the status quo. This silence type is related to learned helplessness behavior (Taşkıran, 2011).

\section{Defensive Silence}

It appears in the form of employees keeping silent since they are scared of the reactions when they state their opinions. It is a conscient behavior that the employee exhibits in order to fend off threats. The differences in regard to silence dimension between defensive silence and acquiescent silence are shown in figure 4.1 .

\section{Pro-social Silence}

Pro-social silence can be defined as the employees not expressing their thoughts, knowledge and opinions to benefit the organization or to keep it from harm. Pro-social silence overlaps with altruism which is a sub-dimension of citizenship behavior. On the basis of organizational citizenship behavior lies helping other employees within the organization voluntarily (Kardam, 2006). We can illustrate this with an employee who keeps silent about the problems at work in order to protect a colleague.

To understand the relationship between knowledge sharing and organization culture, the subject of knowledge management, which is prominent at the present time due to the extensive use of web technologies, should be investigated. Knowledge management can be briefly summarized as collecting knowledge from the vicinity of the organization, converting it into a systematically usable knowledge and sharing it among the employees of the organization. In an organization, two dimensions of knowledge exist.

These are explicit knowledge and tacit knowledge. Explicit knowledge is the knowledge written in the databases and understood by anyone. Explicit knowledge consists of things we can say; it is the knowledge that can be coded and transferred using a language.

Table 1: Dimensions of Defensive and Acquiescent Silence (Taşkıran, 2011)

\begin{tabular}{|c|c|c|}
\hline & Defensive & Acquiescent \\
\hline Willingness & Highly willing & Lower conscious \\
\hline Consciousness & Conscious & High \\
\hline Resignation & Low & Low \\
\hline Stress Level & High & Low \\
\hline Awareness of Alternatives & High & Low \\
\hline Utterance Tendency & High & Low \\
\hline Abandonment Tendency & High & Acquiescence, obeying \\
\hline Dominant Emotions & Fear, desperateness, depression & \\
\hline
\end{tabular}


Documents, instructions, graphs and all other media that can be stored and transferred includes explicit knowledge. On the other hand, tacit knowledge is more personal and context (Barker, 2002)-. Tacit knowledge is a concept that is difficult to formalize and understand, and is related to organization culture. An example for tacit knowledge is the team and solidarity spirit that allows the personnel to work together (Eren, 2009). Our opinions that whether or not a client would buy a product, or a process would result in a correct outcome based on complex variable alternatives, are tacit knowledge. Generally, tacit knowledge is far more comprehensive than explicit knowledge. The knowledge that can be expressed in words and numbers, is nothing more than the tip of the cognitive iceberg. Tacit knowledge is something only possessed by individuals. For this knowledge to be socialized within the organization, a "space", that would give way to interaction of people through various types of dialogs, needs to be created (Barker, 2002).

We can further divide tacit knowledge into two: cognitive tacit knowledge and technical tacit knowledge. Cognitive tacit knowledge can be associated with cognitive models where as technical tacit knowledge can be associated with skillfulness (Göksel).

Since tacit knowledge originates from long-term experience and accumulation, unlike explicit knowledge, it is impossible to share it by turning it into symbols to formalize. Tacit knowledge can be shared with slower processes in form of master-apprentice relationship (İbicioğlu \& Doğan, 2006).

Learning of an organization starts with information processing activities. Although explicit knowledge is easier to process and distribute, as it was previously stated, tacit knowledge is extremely challenging to format, store and distribute. Still, in favor of organizational learning, the cognitive and technical tacit knowledge possessed by employees should somehow be rendered shareable and usable in line with organization's mission (Koçel, 2011).

Telling and listening to stories, banter, a little gossiping is the most fundamental way for people in organization to trust and understand one another. In such conversations, colleagues share plenty of technical specialized knowledge among themselves. The conversationalists do not only develop expertise, but also a common language (Kohen \& Laurence, 2001).

The general culture characteristics that should be established, concerning the destruction of fear culture and interception of formation of silence climate, can be summarized as follows (Mcgill \& Slocum, 1993):

1. Openness to experiences

2. Encouragement of risk-taking responsibility

3. Openness to learning from mistakes

Learning process actualizes as making mistakes and learning lessons from them. To make mistakes, responsibility and taking risks are mandatory. To encourage employees to take risks and responsibility, they should primarily be allowed to make mistakes. This can be achieved through employee empowerment which means allowing employees freedom and letting them participate in decision making about their work (İbicioğlu \& Doğan, 2006).

In conflicted environments with a low level of trust, there are always a number of reasons to reject an idea. The complication is not in the seeds of the ideas, rather, in the stiffness and infertility of the soil those seeds seeking to take root in (Gerzon, 2006). Mediators within organizations need to establish an environment that is convenient for innovative ideas (Isaacs, 1999). To that end, leaders -along with their close counsels- have to analyze the current state, determine what needs to be modified, and envision a distinct situation (Gardner, 2006).

In corporate organizations, managers are required to establish a likely environment in order to encourage employees with innovative ideas. Kuratko and Hodgetts proposes the following items as required activities in favor of building such an environment:

1. Encouraging activities.

2. Conducting informal meetings when possible.

3. Showing tolerance towards mistakes.

4. Recognizing these mistakes as a learning experience.

5. Rewarding the personnel possessing innovative ideas.

6. Keeping non-formal communication channels open. 
7. Forming teams for future projects.

8. Eliminating stiff business processes and red-tape (Daft, 1997).

It is also possible to correlate encouragement of employees having innovative ideas with corporate entrepreneurship concept. In the 1990 study by Kuratko, Montagno and Hornsby, four factors are of essence in regards to development of corporate entrepreneurship. These are the support of management, organizational structure, rewarding and the opportunities of employees to use resources. In the 2004 study of Joseph, seven factors are emphasized in terms of development of corporate entrepreneurship. These can be summarized as follows (Srivastavaand \& Agrawal, 2010):

1. Risk awareness and in case of an opportunity, taking calculated risks.

2. Authorization and empowerment.

3. Acquiescence of change and uncertainty.

4. Network organization structure.

5. Reward and motivation practices that encourages entrepreneurship.

6. Promoting teamwork.

7. Showing tolerance towards mistakes.

\section{Consequences of Organizational Silence Climate}

There exist plenty of dire consequences of organizational silence climate with regards to organizations. Especially in our days, the information era, it prevails consequences directly on the competitive structure of the business.

- Silence climate adversely affects the trust and motivation of employees in organizations

- By causing employees to put up resistance to change, it impairs innovation, development processes and creativity.

- It causes employees to drift apart from one another and isolate themselves from the organization, thereby becoming alienated.

- It leads to a drop in productivity of employees.

- It adversely affects the job satisfaction of the personnel and their commitment to the organization.

- It obstructs identification and correction of mistakes due to the lack of feedback.

- As the problems are not diagnosed properly, it reduces the efficiency of organizational decisions.

- It increases leave of employment, which causes high employee turnover rates (Morrison \& Milliken, 2000).

Additionally, organizational silence excites in the employee, feelings of humiliation, a sense of resentment, even grudge against other personnel. If precautions are not taken, silence climate may infect all the relations within the organization (Alparslan \& Kayalar, Örgütsel Sessizlik: Sessizlik Davranışları ve Örgütsel ve Bireysel Etkileri, 2012).

\section{Conclusions}

In modern days, we have entered the information age with the rapid development in computer technology, especially the start of using the Internet. In the information age, the dominant and the most important production factor in the new economic order that we call digital economy, is the knowledge. Using knowledge accurately and producing new knowledge carries strategic importance from the viewpoint of modern corporations. Therefore, it is imperative to establish an organization culture that would allow sharing ideas within the organization. In regards to formation of organization culture, first of all, specific values should arise from assumptions and a unity of beliefs should be constructed around these values.

As a proposal, the significance of knowledge sharing should rank among basic values within the organization. The unity of beliefs that needs to be established in a corporation like this should be "constant knowledge sharing for constant change and innovation". As a result, in order to have a strong organization culture that is tightly-knitted around these beliefs and values, a setting where the employees can express their opinions without fear should be established. An organization culture established in such manner would prevent organizational silence from becoming a climate in the organization. 


\section{References}

Alparslan, A. M. (2010). Örgütsel Sessizlik İklimi ve İş gören Sessizlik Davranışları Arasındaki Etkileşim. Isparta: Sületman Demirel Üniversitesi Yüksek Lisans Tezi.

Alparslan, A. M., \& Kayalar, M. (2012). Örgütsel Sessizlik: Sessizlik Davranışları ve Örgütsel ve Bireysel Etkileri. Mehmet Akif Ersoy Üniversitesi SBE Dergisi(6), 136-147.

Aşkun, B., Bakoğlu, R., \& Berber, A. (2009). Remaining Silent or Not: Is Power Distance a Barrier For Academicians. Internation Conference on Social Science. İzmir.

Barker, A. (2002). Yenilikçiliğin Simyası. İstanbul: MESS Yayınları.

Bayat, B. (2002). Örgütlerde Güdülenme Yetersizlikleri ve Geri Çekilme - Kaçınma Davranışlarını Açıklamakta Kullanılabilecek Bir Model: Öğrenilmiş Çaresizlik. Gazi Üniv. İ.I.B.F. Dergisi, 4(3), 4.

Burçin, N. (2012). İşletmelerde Örgütsel Sessizliğin Örgütsel Bağlılık ve İş Tatminine Etkisi Üzerine Bir Araştırma. Adana: Çukurova Üniversitesi.

Çakıc1, A. (2007). Örgütlerde Sessizlik: Sessizliğin Teorik Temelleri ve Dinamikleri. Ç.Ü. Sosyal Bilimler Enstitüsü Dergisi, 16(1), $145-162$.

Çemberci, M. (2012). Örgütsel Öğrenmenin AR-GE Takımlarının Performansı Üzerine Etkileri. İstanbul: Ati Yayınları.

Daft, L. R. (1997). Management. Foth Worth: The Dryden Press.

Doğan, B. (2007). Örgüt Kültürü. İstanbul: Beta.

Durak, İ. (2012). Korku Kültürü ve Örgütsel Sessizlik. Bursa: Ekin Basım Yayın Dağıtım.

Eren, E. (2009). Yönetim ve Organizasyon. İstanbul: Beta.

Erenler, E. (2010). Çalışanlarda Sessizlik Davranışının Bazı Kişisel ve Örgütsel Özellikler ile İlişkisi: Turizm Sektöründe Bir Alan Araştırması. Ankara: Hacettepe Univ. Doktora Tezi.

Eroğlu, E. H., Adıgüzel, O., \& Öztürk, U. (2011). Sessizlik Girdabı ve Bağlılık İkilemi: İş gören Sessizliği ile Örgütsel Bağlılık İlişkisi ve Bir Araştırma. Sessizlik Girdabı ve Bağlllık İkilemi: İş gören Sessizliği ile Örgütsel Bağlllık Süleyman Demirel Üniversitesi İktisadi ve İdari Bilimler Fakültesi Dergisi, 6, 97-124.

Essounga, Y. (2009). A Review of the Effects of National Culture on Corporate Culture: An Example of the United States and France. 9(5), 71.

Gardner, H. (2006). Zihniyetleri Değiştirmek Kendimizin ve Başkalarının Zihniyetini Değiştirmenin Sanatı ve Bilimi. İstanbul: MESS Yayınları.

Gerzon, M. (2006). Çatışmalı Ortamlarda Liderlik Başarılı Liderler Farklılıkları Nasıl Fırsatlara Dönüştürüyor. İstanbul: MESS Yayınlar1.

Göksel, A. (tarih yok). Örgütlerde Bilgi Paylaşım Davranışı: Sosyal Sermaye Boyutundan Bir Bakış. Ankara Üniv. SBF Dergisi, 65(4), 89.

Gül, H., \& Nazlı Özcan. (2010). Mobbing ve Örgütsel Sessizlik Arasındaki İlişkiler: Karaman İl Özel İdaresinde Görgül Bir Çalışma. IIIBF, 17, 107-134.

Huang, X., Vegt, G., \& Viert, E. (2005). Breaking the Silence Culture: Stimulation of Participiation and Employee Opinion Withholding Cross-Nationally. Management and Organization Review, 1(3), 462.

İbicioğlu, H., \& Doğan, H. (2006). İşletmelerde Örtülü Bilgi ve Önemi. Bursa: Ekin Kitapevi.

Isaacs, W. (1999). Dialogue and the Art of Thinking Together. New York: Random House.

Kahveci, G., \& Demirtaş, Z. (2013). Öğretmenler içi Örgütsel Sessizlik Ölçeği Geliştirme Çalışması. Elektronik sosyal bilimler Dergisi, 12(43), 167-182.

Çatışmalı Ortamlarda Liderlik Başarılı Liderler Farklılıkları Nasıl Fırsatlara Dönüştürüryor? (2006). (A. Kardam, Çev.) İstanbul: MESS Yayınları.

Keith, D. (1988). İşletmede İnsan Davranışı Örgütsel Davranış. İstanbul: İstanbul Üniv. İşletme Fak. .

Koçel, T. (2011). İşletme Yöneticiliği. İstanbul: Beta. 


\section{Civelek et al. /International Journal of Research in Business and Social Science}

Vol 4, No 4, 2015 ISSN: 2147-4478

Kohen, D., \& Laurence, P. (2001). Kavrayamadı̆̆ımız Zenginlik Kuruluşların Sosyal Sermayesi. İstanbul: MESS Yayınları.

Mcgill, M., \& Slocum, J. (1993). Unlearning the Organization. Organizational dynamics.

Mooji, M., \& Hofstede, G. (2010). The Hofstede Model. International Journal of Advertising, 29(1), 88-90.

Morgan, G. (1998). Yönetim ve Örgüt Teorilerinde Metafor. İstanbul: MESS Yayınları.

Morrison, E. W., \& Milliken, J. (2000). Organizational Silence: A Barrier to Change and Development in a Pluralistic World. Acadeny of Management, 25(4), 718.

Örgütsel Vatandaşl1k. (2010). Kahramanmaraş Sütçü İmam Üniversitesi İ̈BF Dergisi.(3), 36.

Özdemir, L., \& Sarığlu Uğur, S. (2013). Örgütsel Ses ve Sessizlik” Algılamalarının Demografik Nitelikler Açısından Değerlendirilmesi: Kamu ve Özel Sektörde bir Araştırma. Örgütsel Ses ve Sessizlik” Algılamalarının Demografik Nitelikler Açısından DeğerlendirilmesiAtatürk Üniversitesi İktisadi ve İdari Bilimler Dergisi,, 27(1), 257-281.

Özgen, I., \& Sürgeyil, O. (2009). Turizm İşletmelerinde Örgütsel Davranış. Bursa: MKM Yayıncılık.

Senge, P. (2004). Beşinci Disiplin. (A. İldeniz, \& A. Doğukan, Çev.) Yapı Kredi Yayınları.

Soycan, S. H. (2010). Bankalarda Birleşme Sonrası Örgütsel Bağl1lık ve Örgütsel Sessizlik İlişkisi. Marmara Univ. Yüksek Lisans Tezi.

Srivastavaand, N., \& Agrawal, A. (2010). Factors Supporting Corporate Entrepreneurship: An Exploratory Study. TheJournal of Business Perspective, 14(3), 164.

Tangiralay, S., \& Ramanujam, R. (2008). Employee Silence on Critical Work Issues: The Cross Level Effects of Procedural Climate. Personal Pyschology, 61, 39.

Taşkıran, E. (2011). Liderlik ve Örgütsel Sessizlik Arasındaki Etkileşim. İstanbul: Beta.

The Hofstede Model. (2010). International Journal of Advertising, 29(1), 88-90.

Turhan, M. (1987). Kültür Değişmeleri. İstanbul: Marmara Üniversitesi İlahiyat Fakültesi Vakfı Yayınları Yayın No 16.

Türk Dil Kurumu Büyük Türkçe Sözlük. (tarih yok). 09 15, 2015 tarihinde http://tdkterim.gov.tr/bts/ adresinden alındı 